INOBIS: Jurnal Inovasi Bisnis dan Manajemen Indonesia

Volume 1, Nomor 1, Desember 2017

Muhammad Sabir Mustafa

\title{
Konsep Pengembangan UMKM Berbasis Pengukuran Kinerja
}

\author{
Muhammad Sabir Mustafa \\ Mahasiswa Doktor Manajemen Universitas Brawijaya
}

\begin{abstract}
Abstrak
Para scholars telah memperingatkan krisis organisasi di UKM. Banyak faktor yang telah disarankan memiliki kontribusi terhadap krisis ini. Di antara yang paling sering disebutkan adalah: perubahan pada lingkungan manufaktur, penurunan siklus hidup produk, Isu saat ini dan teks arsip. UKM biasanya berperilaku dengan cara yang reaktif, sehingga tingkat strategis perencanaan adalah kurang dan tidak ada proses pengambilan keputusan formal.
\end{abstract}

Keyowords: UMKM, Strategi, Perencanaan, Kinerja

\section{Pendahuluan}

Tujuan penelitian ini adalah untuk menyelidiki kedua jalan yang ditempuh oleh perusahaan dalam rangka bertahan di lingkungan yang kompetitif dan faktor-faktor yang disukai atau terbatas pada pembangunan mereka.

Para scholars telah memperingatkan krisis organisasi di UKM. Banyak faktor yang telah disarankan memiliki kontribusi terhadap krisis ini. Di antara yang paling sering disebutkan adalah: perubahan pada lingkungan manufaktur, penurunan siklus hidup produk, Isu saat ini dan teks arsip. UKM biasanya berperilaku dengan cara yang reaktif, sehingga tingkat strategis perencanaan adalah kurang dan tidak ada proses pengambilan keputusan formal. Kurangnya strategi eksplisit dan metodologi untuk mendukung proses kontrol menyebabkan baik visi jangka pendek dan orientasi (Brouthers. et.al, 1998; Marchini, 1995). Kontribusi di bidang pengembangan organisasi dalam usaha kecil memiliki meningkat secara signifikan di kalangan akademisi dan praktisi dalam beberapa dekade terakhir. Walaupun studi empiris telah menyoroti pentingnya organisasi aspek dalam mendukung pengembangan UKM (Astrachan dan Shanker, 2003; Heck dan Stafford, 2001; Hisrich dan Drnovšek, 2002), banyak hal masih belum cukup diselidiki.

Untuk memberikan kontribusi untuk penelitian pada pengembangan UKM, penelitian ini mencoba untuk menemukan jawaban atas pertanyaan-pertanyaan berikut:

1. Bagaimana UKM berevolusi untuk dapat bertahan dalam lingkungan yang sekarang berkompetitif?

2. Bagaimana bisa ditingkatkan kemampuan organisasi untuk mempertahankan pembangunan perusahaan-perusahaan ini?

\section{Tinjuan Pustaka}

Beberapa studi empiris telah dilakukan pada kemampuan organisasi, khususnya pada UKM, tapi beberapa definisi telah diajukan oleh para sarjana dalam 15 tahun terakhir (Lihat misalnya Dosi et al, 2002;. Harvey dan Jones, 1992; Helfat, 2003; Ulrich dan Danau, 1991). Mulai dari analisis ini, dalam penelitian ini, kemampuan organisasi telah diteliti sebagai kemampuan perusahaan untuk mengelola proses manajerial, yaitu proses yang terutama mempengaruhi manajemen cara beroperasi ketika membuat keputusan dan pengendali (Teece 
INOBIS: Jurnal Inovasi Bisnis dan Manajemen Indonesia

Volume 1, Nomor 1, Desember 2017

Muhammad Sabir Mustafa

et al, 1997;. Dyer dan Singh, 1998). Proses ini menentukan seberapa baik keunggulan kompetitif ditopang dan diidentifikasi dengan mengadopsi logika yang digunakan oleh Porter (1987) untuk mendefinisikan rantai nilai. Makro-proses diidentifikasi dapat dikelompokkan bersama ke dalam tiga jenis berikut (Garengo et al, 2005a.):

1. Manajemen makro-proses, yaitu manajemen dan ekonomi - perencanaan keuangan

2. Dukungan makro-proses, manajemen yaitu teknologi informasi dan manajemen personalia, dan

3. Makro-proses operasional, yaitu pengembangan produk, pemasaran, produksi dan pembelian.

Adalah penting untuk menunjukkan bahwa dalam penelitian ini kajian pengembangan organisasi tidak dipertimbangkan. Hal ini disebabkan oleh fakta bahwa arus penelitian ini terutama berfokus pada perilaku organisasi dan aspek struktural, dan jarang menganggap sistem manajerial.

Sejauh UKM yang bersangkutan, tampaknya ada dua pendekatan utama untuk belajar koherensi ini. Beberapa ahli berpendapat bahwa perkembangan manajerial biasanya hanya datang kemudian, setelah perubahan strategi. Keterlambatan ini dapat dikaitkan baik kepada perlu untuk segera merespon tuntutan bisnis baru dan untuk inersia internal dan perlawanan untuk mengubah (Gray, 2002). Penulis lain berpendapat bahwa berikut perubahan strategi manajerial karena strategi tunduk pada pengaruh orang dan untuk pengetahuan organisasi (Peters, 1984). Dalam UKM, strategi sering implisit dan merupakan hasil dari tujuan dan preferensi pengusaha saja (Mintzberg, 1989; Miller dan Toulouse, 1986; Boldizzoni dan Serio, 2006). Sebagai akibatnya, kemampuan organisasi mempengaruhi semua aspek kehidupan perusahaan, dan strategi tertentu.

Beberapa penulis berpendapat bahwa koherensi ini berkembang dengan cara deterministik dan mengusulkan model evolusi berdasarkan siklus hidup organisasi (Dodge et al, 1994.; Greiner, 1972; Kimberley dan Miles, 1980; Miller dan Friesen, 1983; Quinn dan Cameron, 1983; Scott, 1971). Perbedaan pola strategi, struktural karakteristik, dan gaya pengambilan keputusan yang diusulkan dalam konfigurasi daur-hidup membantu untuk menyederhanakan realitas; mereka menganggap bahwa organisasi berkembang mengikuti diprediksi pola, atas berbagai tahap pembangunan.

Model siklus hidup sering berhubungan dengan pertumbuhan perusahaan, yaitu pertumbuhan volume bisnis, juga disebut pertumbuhan bisnis. Beberapa penulis telah melakukan empiris penelitian tentang faktor yang mempengaruhi pertumbuhan UKM misalnya, umur, lokasi, status hukum dan industri, sumber daya daerah yang spesifik, hubungan eksternal dan jaringan konfigurasi (Storey, 1994; Glancey, 1998; Hall, 1987; Hall dan Adams, 1994; Davidsson et al, 2002). Dalam studi ini, evolusi sistem manajerial disajikan sebagai konsekuensi dari pertumbuhan perusahaan. Literatur tentang pengendalian manajemen menjelaskan perubahan sistem formal dalam akuntansi manajemen dan sistem kontrol yang penting untuk perubahan organisasi di seluruh tahap siklus-hidup (Moores dan Yuen, 2001; Davila dan Foster, 2005).

Pertumbuhan UKM sering digunakan seolah-olah itu identik dengan kedua pertumbuhan ukuran perusahaan - pertumbuhan kuantitatif - dan perkembangan di dalam praktek manajerial dan sistem - pertumbuhan kualitatif atau pertumbuhan organisasi. Studi semacam mengadopsi pendekatan deterministik, yang secara implisit mengasumsikan bahwa dimensi kualitatif meningkatkan langkah demi langkah untuk pertumbuhan paralel kuantitatif, yaitu dengan kemampuan untuk mengadopsi lebih teknik manajemen rasional dan untuk mengembangkan budaya manajerial mampu menangani fenomena yang kompleks. Ada bukti bahwa pembangunan kualitatif tidak tentu bertepatan dengan pertumbuhan 
INOBIS: Jurnal Inovasi Bisnis dan Manajemen Indonesia

Volume 1, Nomor 1, Desember 2017

Muhammad Sabir Mustafa

perusahaan dan, di UKM, proses ini seringkali mengambil tempat pada waktu yang berbeda. Sebuah penelitian yang dilakukan oleh Boldizzoni et al. (2000) menunjukkan bahwa, dalam konteks Italia, lebih dari 90 persen dari perusahaan-perusahaan belajar tidak meningkatkan dalam ukuran sedangkan beberapa memang meningkatkan tingkatorganisasi mereka. Banyak perusahaan go melalui pengembangan evolusi non-linear, yaitu mereka mengikuti strategi berdasarkan kualitatif pertumbuhan tanpa meningkatkan ukuran bisnis mereka. Memang, ukuran sebagai indikator pertumbuhan menjadi kurang penting ketika perusahaan mulai mengeksternalisasi proses kunci.

Apapun pendekatan, ada konsensus bahwa kemampuan organisasi harus dapat mengembangkan perusahaan. Satu kontradiksi tampaknya menjadi jelas dalam literatur: organisasi dan manajerial sistem ini sering dianggap tidak cocok untuk memenuhi kebutuhan perusahaan tetapi tidak ada model atau alat diakui sebagai efektif untuk menilai pengembangan manajerial dan kemampuan organisasi (Dressler, 2004). Beberapa investigasi empiris telah dilakukan pada sistem yang diperlukan untuk mendukung manajerial pertumbuhanUKM.

\section{Metodologi Penelitian}

Selama lima tahun terakhir, para penulis makalah ini telah melakukan penelitian mendalam pada aspek organisasi di UKM Italia untuk menemukan cara-cara mendukung UKM pengembangan (misalnya Beradaptasi Developnet; L. 236 Aksi System; Web Pusat Transfer Benchmarking pada Praktek Manajerial bagi UKM).

Mengadopsi pendekatan retrospektif, yaitu belajar dari pengalaman dengan melihat ke belakang atas apa yang telah terjadi dan mencapai kesimpulan tentang hal itu (Mumford, 1995).

Survei deskriptif (Forza, 2002) menggunakan data dari 100 perusahaan yang menanggapi survei kuesioner.

Tujuannya tidak pengembangan teori (Malhotra dan Grover, 1998; Dubin, 1969). Mengingat kurangnya studi empiris tentang topik ini

Penelitian dilakukan tanpa hipotesis yang telah ditetapkan untuk menguji.

Objek analisis UKM dikelompokkan berdasarkan parameter yang ditetapkan oleh Komisi Eropa (lihat Storey, 1994) dengan beberapa spesifikasi lebih lanjut berasal dari (1987) definisi Scott dan Bruce.

Spesifikasi ini dijelaskan di bawah ini dan memungkinkan kita untuk lebih menentukan objek kita analisis.

1. Perusahaan yang beroperasi di sektor manufaktur.

2. Daerah operasi terutama lokal. Pekerja dan pemilik merupakan bagian dari salah satu masyarakat, tetapi pasar belum tentu lokal.

3. Jumlah karyawan adalah antara 20 dan 250.

4. Perusahaan keluarga tidak termasuk kelompok ini, UKM yang diteliti adalah mereka yang sangat tergantung pada pembuat keputusan tunggal, yaitu pemilik mengambil semua utama keputusan bisnis.

5. Penelitian dianggap UKM yang telah terlibat dalam setidaknya satu organisasi krisis dalam lima tahun terakhir (2001 sd 2005). Semua perusahaan yang diteliti telah mengatasi setidaknya satu krisis organisasi sebelum mengambil bagian dalam studi kami dan beberapa dari mereka memutuskan untuk mengambil bagian dalam studi untuk mengatasi krisis dan sebagai konsekuensi dari partisipasi dalam penelitian ini, mereka masih di pasar yang kompetitif. 
INOBIS: Jurnal Inovasi Bisnis dan Manajemen Indonesia

Volume 1, Nomor 1, Desember 2017

Muhammad Sabir Mustafa

6. Dalam studi ini kami menganalisis perusahaan manufaktur. Diperkirakan bahwa pilihan ini akan menyederhanakan studi tentang pertanyaan penelitian karena perusahaan-perusahaan ini dianggap sangat sensitif terhadap topik ini dan mereka memiliki pengalaman dengan pengembangan perusahaan.

7. Data dikumpulkan dengan menggunakan kertas dan kuesioner online yang berfokus pada kapabilitas organisasi. The Seven makro-processes yang terjadi sebelumnya disebut sebagai penentu kemampuan organisasi diubah menjadi diamati dan elemen terukur - juga disebut membangun operasionalisasi (Tabel 1) Setiap proses diselidiki dengan menggunakan alat standar yang codifies praktek manajerial masing-masing proses dalam kartu skor (Tabel II). Menggunakan pendekatan pembandingan berdasarkan Voss et al 's. (1994) pendekatan, kami dapat mengetahui tingkat kemampuan organisasi.

8. Sebagai tambahan, untuk setiap perusahaan, kami mengumpulkan informasi tentang faktor-faktor utama bahwa krisis mempengaruhi organisasi menggunakan kedua pertanyaan terbuka dan data dikumpulkan selama proyek sebelumnya. Untuk melakukan hal ini, kedua pertanyaan faktual dan tanggap yang diformalkan. pertanyaan tanggap diterapkan untuk kompleks dan tidak langsung diamati pertanyaan. Jawaban diklasifikasikan membuat referensi ke tujuh proses makro disebutkan sebelumnya.

\section{Hasil Penelitian}

Sejumlah besar data pada proses manajerial dianalisis dan digunakan untuk mempelajari kemampuan organisasi dalam perusahaan yang diselidiki. Perkembangan ratarata proses manajerial di perusahaan diselidiki diringkas dalam Gambar 1 (hasil didasarkan pada skala $0-8$, nilai 4 dianggap threshold).

Gambar 1 menawarkan snapshot dari perkembangan-proses makro di perusahaan diinvestigasi bila dianggap sebagai sebuah kelompok. UKM akan dinvestigasi tampaknya cukup jauh dari praktik terbaik (nilai 8). Sebagian besar dari proses makro adalah antara 4 dan 5 dan kemampuan organisasi mereka sanga kurang (poor) tapi cukup baik untuk kelangsungan hidup perusahaan. Disimpulkan, perusahaan masih berada di pasar yang kompetitif dan mereka semua mengatasi krisis organisasi dalam lima tahun terakhir.

Banyak faktor yang tampaknya telah menimbulkan krisis organisasi dalam perusahaan yang dianalisis. Faktor-faktor ini secara singkat dirangkum di bawah ini membuat rujukan kepada kegiatan-proses makro diinvestigasi.

1. Strategi dan perencanaan. Di hampir semua perusahaan, perubahan strategi dilakukan keluar tanpa membawa dampak organisasi mereka ke dalam account. Percobaan mereka dengan model bisnis baru dengan mengadopsi cara-cara menanggapi pasar yang menawarkan tingkat fleksibilitas yang lebih tinggi, variasi dan modularisasi produk, dan dengan mengembangkan konten layanan untuk kedua produk dan jasa terkait. Namun, percobaan ini adalah tidak diformalkan. Mereka berinvestasi dalam teknologi baru untuk produk dan proses, namun perubahan strategi dan manajemen tidak dipertimbangkan. Driver hanya perubahan yang dirasakan adalah kebutuhan pasar.

2. Manajerial kontrol. Dalam sejumlah perusahaan besar, tata kelola perusahaan menghalangi pertumbuhan struktur manajerial. Tumpang tindih antara kepemilikan,perusahaan dan keluarga membawa sekitar kompleks struktur tata kelola perusahaan. Tumpang tindih mempengaruhi tingkat delegasi, kontrol dan sistem 
INOBIS: Jurnal Inovasi Bisnis dan Manajemen Indonesia

Volume 1, Nomor 1, Desember 2017

\section{Muhammad Sabir Mustafa}

manajemen dan semua tindakan organ formal. Kekuasaan pengambilan keputusan tentang strategis dan masalah-masalah manajerial terletak pada pemilik dan ini menghambat kegiatan manajerial dan krisis organisasi. Pengusaha bertanggung jawab atas kedua fungsi operasional dan manajerial, dia biasanya menghalangi mengabaikan kegiatan manajerial dan pengembangan perusahaan.

Tabel I. Macro-Process and Area of Activity in SMEs

\begin{tabular}{ll}
\hline Macro-processes & Areas of activity \\
\hline Management and economic-financial planning & $\begin{array}{l}\text { Strategy and planning } \\
\text { Performance measurement } \\
\text { Budgeting }\end{array}$ \\
Managerial control \\
Continuous improvement management \\
Customer relationship management \\
Market research management \\
Marketing information system \\
Price strategy \\
Distribution strategy \\
International marketing management \\
Distribution network management \\
External commumications strategy \\
Internet marketing \\
Forecasting \\
Product strategies development \\
Design-production-suppliers integration in product \\
development \\
New product production \\
Project management \\
Design for environment \\
Management of the product development process \\
Product data management \\
\end{tabular}


INOBIS: Jurnal Inovasi Bisnis dan Manajemen Indonesia

Volume 1, Nomor 1, Desember 2017

\section{Muhammad Sabir Mustafa}

Production

Purchasing

Personnel management

Management information system

Tabel II. Codifies Praktek Manajerial

Source: Adapted from Garengo et al (2005a)

\author{
Aggregate planning \\ Master production scheduling \\ Final assembly scheduling (FAS) \\ Customer order processing \\ Material requirement planning and inventory \\ management \\ Warehouse management \\ Capacity requirement planning \\ Order release \\ Scheduling \\ Data acquisition and monitoring \\ Shopfloor control \\ Vendor rating \\ Check on incoming materials \\ Supplier management \\ Purchasing database management \\ Recruitment and hiring \\ Job evaluation \\ Performance evaluation \\ Training and development \\ Evaluation of information technologies needs \\ Use of the company's information technologies \\ system \\ IT function organization
}

\begin{tabular}{|c|c|c|c|}
\hline Level 1 & Level 2 & Level 3 & Level 4 (best practice) \\
\hline $\begin{array}{l}\text { There is no standard } \\
\text { procedure for } \\
\text { developing new } \\
\text { products and for } \\
\text { managing } \\
\text { modifications }\end{array}$ & $\begin{array}{l}\text { The range of products } \\
\text { is periodically reviewed } \\
\text { and new products } \\
\text { introduced. This } \\
\text { requires authorization } \\
\text { for the necessary } \\
\text { investments to } \\
\text { manufacture the new } \\
\text { products. All of the } \\
\text { other stages of the } \\
\text { innovative processes } \\
\text { are not defined }\end{array}$ & $\begin{array}{l}\text { There is a standard } \\
\text { procedure to be } \\
\text { followed to regulate the } \\
\text { development and } \\
\text { launch of new products } \\
\text { and to manage } \\
\text { modifications, } \\
\text { especially for } \\
\text { customizing products }\end{array}$ & $\begin{array}{l}\text { The procedures for the } \\
\text { development of new } \\
\text { products are } \\
\text { differentiated according } \\
\text { to the degree of } \\
\text { innovation of the } \\
\text { project (e.g. new } \\
\text { product or } \\
\text { modifications). The } \\
\text { allocation of resources } \\
\text { for development and } \\
\text { modifications is } \\
\text { planned and controlled } \\
\text { Various indicators for } \\
\text { measuring the } \\
\text { performance of the } \\
\text { development process } \\
\text { have been developed } \\
\text { and data are gathered } \\
\text { regularly and used to } \\
\text { keep this process under } \\
\text { control and improve it }\end{array}$ \\
\hline
\end{tabular}


INOBIS: Jurnal Inovasi Bisnis dan Manajemen Indonesia

Volume 1, Nomor 1, Desember 2017

\section{Muhammad Sabir Mustafa}

3. Pengukuran kinerja. Informasi tentang kinerja perusahaan sering kekurangan. Hanya ada beberapa indikator kinerja tentang produksi efisiensi dan beberapa informasi tradisional tentang biaya produksi. Pendekatan pengukuran kinerja adalah informal, tidak direncanakan dan tidak berdasarkan model standar, beberapa pengukuran kinerja diperkenalkan untuk memecahkan masalah-masalah tertentu seperti krisis organisasi dan kebutuhan untuk meningkatkan pemberdayaan.

4. Perbaikan berkelanjutan. Rasional dan perubahan organisasi yang disengaja tampaknya praktek asing bagi banyak UKM. Praktek manajerial yang terutama dipengaruhi oleh nilai-nilai dan pengetahuan dari pemilik serta sebagai gaya pengelolaan yang ditetapkan oleh mereka. UKM mempelajari lebih memilih untuk menyesuaikan proses dan mengimplementasikan tambahan perbaikan, khususnya di organisasi lapangan. Sebagian besar perusahaan investasi sumber daya dalam aspek organisasi hanya untuk menyelesaikan krisis organisasi dan bukan untuk mencegah mereka.

5. Produksi. Perusahaan dengan metodologi canggih produksi perencanaan dan kontrol menerima pesanan kelebihan kapasitas untuk merespon meningkatnya permintaan pelanggan, produksi sistem kontrol yang jarang digunakan, dan lembur telah untuk menebus kurangnya ketentuan dalam rencana produksi. Kesulitan memenuhi pesanan cukup sering menimbulkan chaos organisasi. Beberapa perusahaan investasi besar jumlah uang dalam proses kunci re-engineering, tapi isi yang sesungguhnya dari intervensi hampir secara eksklusif pada proses manufaktur dan EDP prosedur. Dampak organisasi tidak mempertimbangkan dan praktek manajerial dan perilaku karyawan tidak dipantau.

6. Pribadi manajemen. Kurangnya perhatian kepada sumber daya manusia dan sangat sering karyawan menempati posisi yang berbeda pada saat yang sama. Di hampir semua UKM diselidiki, tidak ada satu orang yang bertanggung jawab atas manajemen sumber daya manusia, dengan pengecualian, dalam beberapa kasus, keberadaan eksternal konsultan. Seringkali karyawan adalah terutama dikelola tanpa sistem oleh pengusaha, dan kinerja individu dan pengetahuan jarang diukur menggunakan sistem ad hoc. Kriteria utama yang digunakan adalah informal dan berdasarkan kepercayaan dan perasaan. Ada beberapa upaya sporadis untuk link rewards produktivitas atau tujuan generik lainnya, namun, kurangnya kinerja formal manajemen merupakan halangan atas penggunaan sistem reward dan proses pemberdayaan. Keterampilan manajerial sering kurang dan karena itu alat manajerial dan teknik yang dianggap sebagai manfaat yang kecil bagi perusahaan. 
INOBIS: Jurnal Inovasi Bisnis dan Manajemen Indonesia

Volume 1, Nomor 1, Desember 2017

\section{Muhammad Sabir Mustafa}

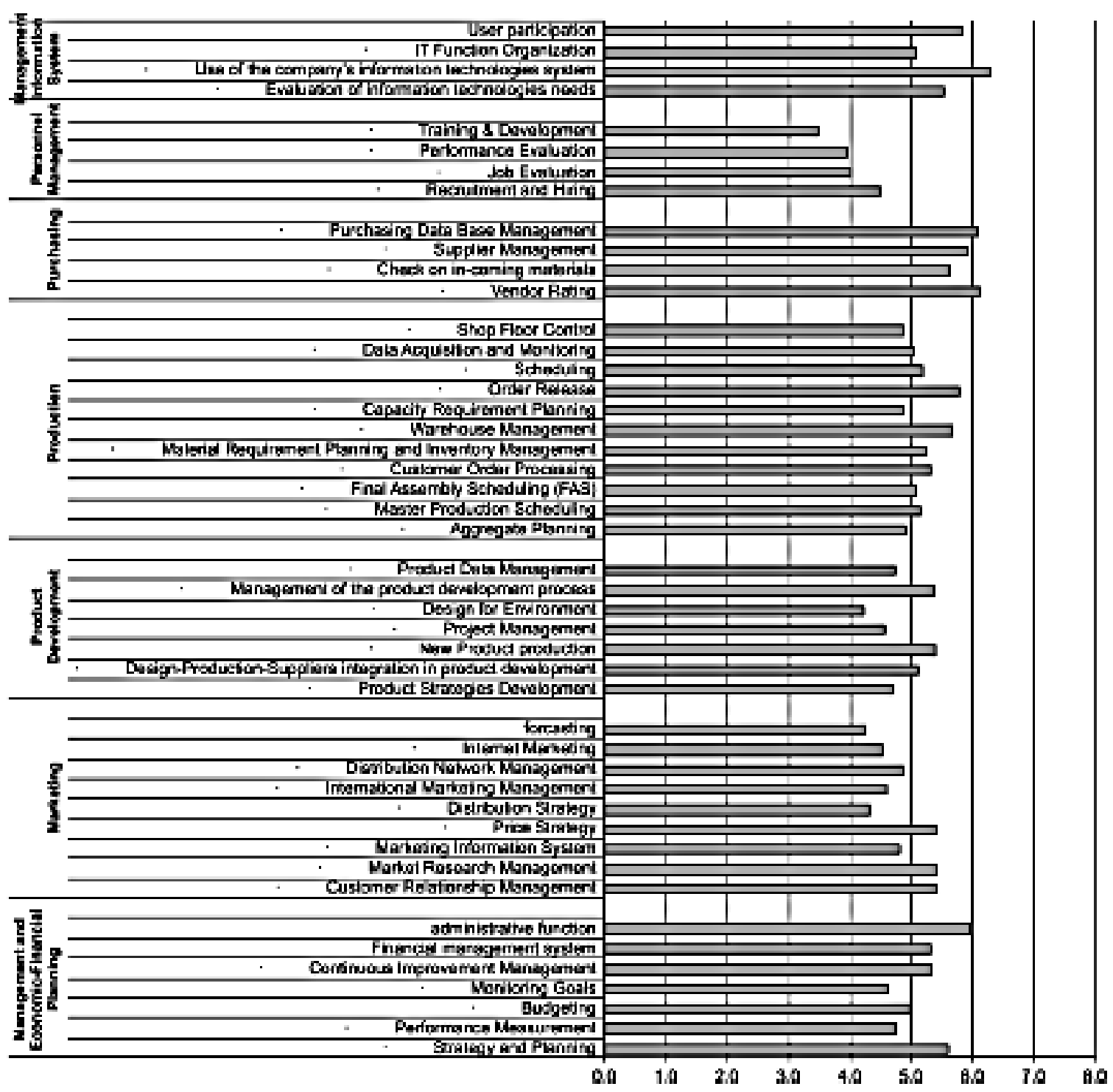

Gambar 1

Macro-process and area of activity of the SMEs investigated

Walaupun temuan ini menunjukkan tingkat ketidakpastian, UKM dipelajari merasa berada dalam keadaan keseimbangan yang nyaman, yaitu dalam situasi yang masih bisa dikelola dan dikendalikan oleh pengusaha.

Pentingnya kemampuan organisasi ditekankan oleh perubahan dalam model bisnis, peningkatan teknologi produk dan proses dan / atau peningkatan volume usaha. Perubahan ini menyebabkan kompleksitas manajerial meningkat dan kekurangan kemampuan organisasi drive perusahaan menjadi krisis organisasi itu, berdasarkan pada penelitian yang dilakukan oleh Pascale (1999), kita bisa memanggil zona chaos, yaitu negara mana masalah yang lebih besar dari kemampuan mereka untuk mengelola (Gambar 2). Untuk mengelola situasi ini, perusahaan dihadapkan dengan dua pilihan utama. Pilihan pertama adalah untuk tidak berinvestasi dalam kemampuan organisasi, sehingga yang tersisa di zona chaos. Namun, ini hanya bisa menjadi negara sementara dan dapat memaksa organisasi dari persaingan pasar. 
INOBIS: Jurnal Inovasi Bisnis dan Manajemen Indonesia

Volume 1, Nomor 1, Desember 2017

Muhammad Sabir Mustafa

Pilihan kedua adalah melakukan investasi pada kemampuan organisasi dalam rangka untuk pergi luar "tepi chaos" dan mencapai keseimbangan baru, yaitu pertumbuhan kualitatif.

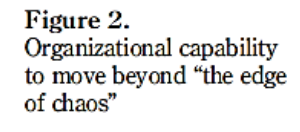

Organizational capability
to move beyond "the edge of chaos"

\section{Gambar 2.}

Untuk menjelaskan dua pilihan diatas, hasil dari investigasi memberikan hasil bahwa untuk bergerak melampaui tepi chaos, perusahaan telah diselidiki diinvestasikan dalam meningkatkan kemampuan organisasi mereka dengan sarana pendukung eksternal atau proyek-proyek yang mendukung pertumbuhan manajerial. Proyek-proyek telah mencoba untuk mempromosikan pengembangan kemampuan organisasi dengan mendukung pelaksanaan kekurangan manajerial proses dan memperbaiki sistem manajerial.

UKM diselidiki belum mampu mengembangkan sistem operasional mereka bersamaan dengan kemampuan organisasi. Mereka bergerak dari "panggung keseimbangan" ke zona chaos ketika mereka tidak lagi mampu mengelola meningkatnya kompleksitas. Mereka telah mampu bertahan hidup hanya jika, dalam waktu singkat, mereka berhasil meningkatkan kemampuan organisasi mereka, sebagai akibatnya, mencari posisi keseimbangan baru. Dengan kata lain, mereka telah berevolusi sepanjang jalur non-linear (Gambar 3).

Sistem manajerial tampaknya merupakan elemen kunci bagi evolusi UKM. Meskipun PMS terpadu belum dilaksanakan, perbaikan dalam organisasi kemampuan telah didorong oleh pengenalan sistem dan alat mampu mendukung proses pengambilan keputusan dengan mengumpulkan, menguraikan dan menganalisis informasi. Karakteristik PMS ditekankan oleh literatur tampaknya menunjukkan bahwa intrinsik karakteristik model PMS dan proses implementasi yang baik bisa menawarkan solusi untuk kebutuhan UKM (Garengo et al, 2005b;. Hudson et al, 2001.). Beberapa penelitian mengidentifikasi tekanan yang berkaitan dengan ukuran kinerja sebagai salah satu kekuatan utama yang mendasari perubahan organisasi dan inovasi (Cyert dan Maret, 1963, dan setelah). Dalam studi terbaru, dampak organisasi PMS sudah mulai diperhitungkan. Penelitian Pengukuran kinerja melampaui pengukuran teknis pertunjukan dan mencakup dimensi pengukuran sistem kinerja manajerial; itu menggabungkan semua sistem perusahaan dan mendukung pengambilan keputusan, kontrol, belajar dan komunikasi (Simons, 2000). 
INOBIS: Jurnal Inovasi Bisnis dan Manajemen Indonesia

Volume 1, Nomor 1, Desember 2017

Muhammad Sabir Mustafa

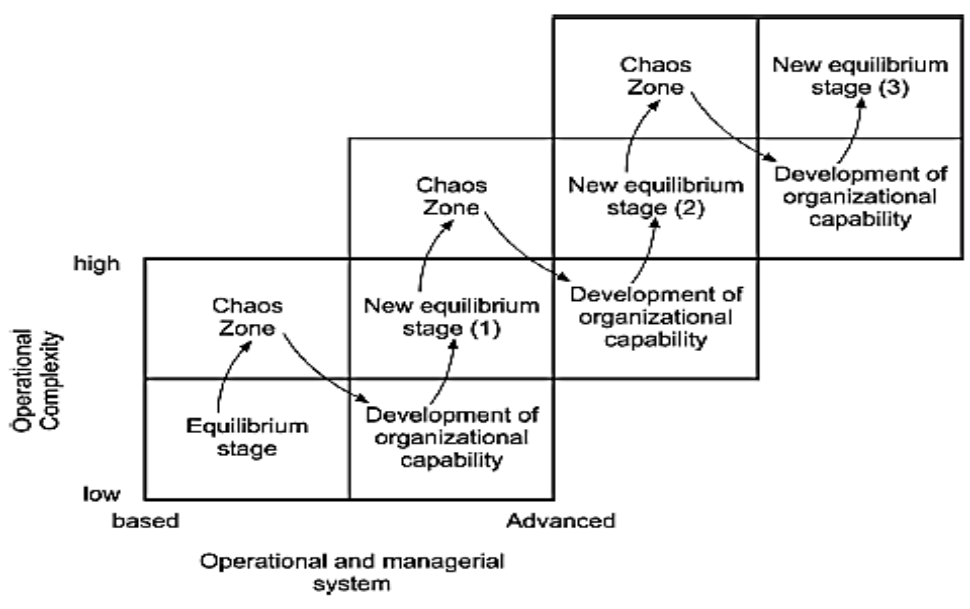

Gambar 3.

Evolusioner jalan diikuti oleh UKM Organisasi kemampuan dalam UKM

Seperti disorot dalam literatur, PMS memberrikan keselarasan strategi dan strategi review. Di satu sisi, PMS termasuk sistem untuk meninjau langkah-langkah dan tujuan yang memungkinkan untuk kedua cepat beradaptasi fokus organisasi dalam merespon perubahan dalam konteks internal dan eksternal dan secara sistematis menilai perusahaan strategi dalam rangka mendukung perbaikan terus-menerus (Bititci et al, 1997, 2000;. Bourne et al, 2000;. Tonchia, 2001; Neely et al, 2002). Di sisi lain, PMS memungkinkan perusahaan untuk mengumpulkan data yang mengukur efektivitas dan efisiensi kegiatan perusahaan sehingga membantu untuk menilai kedua apakah strategi tersebut telah sesuai dan apakah telah mencapai tujuan yang ditetapkan dalam strategi bisnis (Feurer dan Chaharbaghi, 1995; Neely et al, 1995, Suwignjo et al, 2000). Dalam beberapa kasus, pengukuran sistem kinerja menyediakan sebuah kerangka di mana para manajer dapat mendukung anggota tim mereka daripada mendikte mereka. Mengelola kinerja staf dapat dianggap sebagai mekanisme yang efektif untuk mengembangkan staf dan pertumbuhan organisasi.

\subsection{Keterbatasan Penelitian}

Terdapat beberapa keterbatasan yang terindikasi dari jurnal ini. Pertama, penelitian ini menggunakan pendekatan restorika dengan perolehan data utama melalui survey deskriptif melalui kuesioner tapi dalam jurnal ini tidak disertakan kuisionernya. Kedua, dalam jurnal ini tidak jelaskan operasional variabel sehingga akan terdapat perbedaan asumsi antara pembaca dan peneliti. Ketiga, tidak menjelaskan data-data kuantitatif.

\subsection{Rekomendasi Penelitian}

Pada dasarnya penelitian ini telah memberikan kontribusi baru pada pengetahuan pengelolaan UKM. Dapat direkomendasikan untuk pengguna (UKM) dan penelitian lanjutan (Peneliti) sebagai berikut :

1. Penggunaan pengukuran kinerja dengan metode PMS secara kompleks, dengan alasan bahwa pelaksanaan dan penggunaan PMS tidak hanya mendorong perubahan terusmenerus dan evolusi di set pengukuran, tetapi juga mempromosikan pembelajaran organisasi, mengingat kapasitasnya untuk memperoleh, mendistribusikan, menafsirkan 
INOBIS: Jurnal Inovasi Bisnis dan Manajemen Indonesia

Volume 1, Nomor 1, Desember 2017

Muhammad Sabir Mustafa

dan menyimpan pengetahuan (Huber, 1991). Pelaksanaan PMS suatu proses yang berorientasi pendekatan. Sebuah PMS berdasarkan proses bisnis dapat memberikan informasi yang akan memungkinkan UKM untuk lebih pro-aktif dalam memenuhi kebutuhan pelanggan.

2. Untuk menghindari Zona Chaos, sebaiknya UKM menyeimbangkan antara investasi manajerial (kemampuan organisasi) dan investasi operasional.

3. Memperhatikan pemberdayaan keterampilan manajerial dengan memiliki penanggungjawab MSDM di UKM.

4. Melakukan Penelitian dengan menggunakan Mix Method. Yaitu menggabungkan penelitian kuantitatif dan kualitatif.

5. Penelitian lanjutan dapat dilakukan pada lokasi berbeda, misalnya di Indonesia.

\section{Daftar Pustaka}

Patrizia Garengo and Giovanni Bernardi, 2007. Organizational capability in SMEs : Performance measurement as a key system in supporting company development Journal of Productivity and Performance Management Vol. 56 No. 5/6, 2007 pp. 518-532.

Keraf, Sonny dan Dua, Michael, 1998. Ilmu Pengetahuan Sebuah Tinjauan Filosofis, Yogyakarta, Penerbit Kanisius.

Suriasumantri, Jujun S. 1988. Filsafat Ilmu: Sebuah Pengantar Populer. Jakarta: Sinar Harapan.

Moleong, Lexy J. 2010. Metodologi Penelitian Kualitatif. Bandung: PT. Remaja Rosdakarya.

Vela-Jiménez, M.J., Martínez-Sánchez, A., De-Luis-Carnicer, P. dan Pérez-Pérez, M. 2005. The Relationship Between Human Resource Flexibility And Firm Performance: A Structural Equation Analysis With Moderator Effects. Research Report. Ministry Of Science And Innovation (Grant Sej2007-62964/Econ). 